\title{
A Study of Expatriate Vision in V.S. Naipaul's India: a Wounded Civilization
}

\author{
Dr. S. Shanmugam \\ Asst. Prof. of English cum Principal Sri Vidya Mandir College of Arts and Science, Neikkarapatty, Salem-10
}

\begin{abstract}
V.S. Naipaul, one of the greatest Caribbean writers in English, has been a great novelist and travel writer. Expatriate writing occupies a significant position between cultures and countries. It generates theory and defines positions as it constructs a new identity which negotiates boundaries and confines and relates to different temporal and spatial metaphors. Cultures travel, take root or get dislocated and individuals internalize nostalgia or experience amnesia, Writers living abroad live on the margins of two societies and cultural theory is today being created by people who live on the margins. Naipaul himself admits that his magnificent obsession is India.

On one hand we find Surekha Dangwal substantiating Naipaul for his expatriate outlook and on the other we find that Rai Sudha has a contrary view to hold on Naipaul. Naipaul recaptures the idyllic world of his childhood, but it is only an old childhood Hindu world he can peacefully and joyously relate to. Indian landscape has come in for lot of appreciation from V.S.Naipaul. The Dal Lake, Shimla, Jammu and Kashmir, Vijayanagar Empire, Bombay, Calcutta, and Goa harbour are meticulously described. V.S.Naipaul's opinion on India is a prejudiced one.

In short, it can be said that by interweaving Brahmanical past with his Trinidadian present one can project him to be a perfect vehicle to report the microcosm and the macrocosm of the expatriate sensibility in him. Naipaul's ideas seem to be an elemental symbiosis of man and nature that he belongs to. Besides, Naipaul's identity remains the most controversial, yet a successful documentary novel. Expatriate vision is obvious everywhere in his work.
\end{abstract}

V.S. Naipaul, one of the greatest Caribbean writers in English, has been a great novelist and travel writer. He was born in an Indian Brahmin family at Chaguanas in Trinidad in 1932. Naipaul, one of the most original, controversial and the best writers of our time, was born in an impoverished rural, Hindu-speaking area of Trinidad. India has always provided a staple context for V.S.NaipauI, but as a novelist he takes a great risk by looking into India with a western outlook. He is an Indian Brahmin uprooted from the land of his own ancestors and has a complex personality. His grandfather migrated to Trinidad as an indentured labourer. Secondly he is West Indian by birth and growth. Finally, because of his self-made exile he lives as an expatriate in London. Owing to these three factors his personality has become very complex. They are largely responsible for building up his mental faculty.

Expatriate writing occupies a significant position between cultures and countries. It generates theory and defines positions as it constructs a new identity which negotiates boundaries and confines and relates to different temporal and spatial metaphors. Cultures travel, take root or get dislocated and individuals internalize nostalgia or experience amnesia, Writers living abroad live on the margins of two societies and cultural theory is today being created by people who live on the margins. Naipaul himself admits that his magnificent obsession is India. But in his books his mode of thinking is seen as British though he is West Indian by birth and growth. This strange sensibility which can be appropriately termed as "expatriate sensibility" has made his position, his viewpoint fallible.

V.S.Naipaul visited India at the time of Indira Gandhi's Emergency in 1975. His ancestors had left one hundred years earlier. This masterpiece is a production of his journey. He experienced different news reports, politics and his own encounters with ordinary Indians - from a supercilious prince to an engineer constructing housing for Bombay's homeless. He has registered India's manifold complexities. His work India: A Wounded Civilization is a work of astonishing insight and candor.

It is not surprising hence that India: $\boldsymbol{A}$ Wounded Civilization has a tinge of expatriate vision. This expatriate vision serves both as a background and a foreground to the normal vision. V.S.Naipaul is the product of western education and culture and so this complexity of triple identity as a West Indian, English and Indian is seen throughout these novels. The obsession with the three culture is best justified by Naipaul himself in his interview to Dileep Padagonkar, a critic cum writer. Both India: A Wounded Civilization and An Area of Darkness have in themselves realistic of India depicting roots and providing a brilliant study of various characters. This character analyses go hand in hand with Naipaul's whims and fancies. Naipaul has allowed himself to be sentimental of his triple identity and expatriate sensibility with his direct personal and vehement 
attack on India and Indian culture. He assesses Indian life and culture with the Hindu norms of Karma, dharma and moksha and the Western norms of individuality and freedom. His feeling is not contempt but pain at the plight and predicament of India.

The Indian self accepts things with faith whereas the Western self challenges or examines from the individual point of view. This point is further justified by Vasant Patel:

Naipaul's feeling is not contempt but pain at the plight and predicament of India. Naipaul's assessment is of an un-believer Hindu totally ignorant of Hinduism. He himself is not responsible for being an unbeliever, an ignorant Hindu but his ancestors and family background are responsible. (120-121)

Naipaul stands out among the diasporic writers by virtue of not just his alienation and expatriate sensibility but also because of his autobiographical perspectives.

Naipaul's expatriate status captures the texture of the lives of the people of both the cultures. The world depicted in his other novels has endless variation of people and culture. The people who inhabited his novels try to achieve European power and success by imitation of the European culture. Hence "the result is that there is frustration, disappointment and disillusion in their life" (Dangwal,70).

On one hand we find Surekha Dangwal substantiating Naipaul for his expatriate outlook and on the other we find that Rai Sudha has a contrary view to hold on Naipaul. To him "India was wounded by Moslem and British rule" (28). Naipaul himself has a similar point of view to hold: "India is for me a difficult country. It isn't my home and cannot be my home; and yet I cannot reject it or be indifferent to it, I cannot travel only for the sights. I am at once too close and too far" (8-9). Most of the critical insights come from the delicate balance of 'insider' and 'outsider' expatriate vision.

The novelist exhibits his affiliation with both the world-the West and the East and therefore tries to focus on India from his point of view. He builds a powerful series of episodes with the background of Indian landscape, Indian sights and sounds, Indian manners and gestures as only a keenly observant and a sensitive artist can depict them. Naipaul's portrayal of hard and harsh facts of life against the background of Indian landscape is a skilful dissection of the real and its presence beneath the inhuman bestialities of life. His observations naturally tend to focus on his apathy towards his childhood memories.

He is guided by his Western outlook and it appears as if he were a spokesman of England in particular and the Western world in general. He forgets the fact that India has offered a lot to the world. Naipaul's attitude of sympathy and compassion for Muslims is also because of his guilt at the contempt, in which they are held by the Hindus - by their being classified as "unclean". Naipaul is not critical of Muslims for their dirt as he is critical of dirt and defecation in India.

Naipaul has a quest for an Indian identity. Naipaul is talking of Poona, an industrialized city, the Shiv Sena and the chawls in Bombay. His familiarity with his people and place casts a new identity in his writing. There is a glimpse of this identification in the text, "Men handling new machines, exercising technical skills that to them are new, can also discover themselves as men, as individuals" (74). We find instance of his earlier attachment to his ancestral properties. This brought a sense of belongingness in the mind of Naipaul.

Naipaul is all praise for Indian sculpture and architectures. The treatment is personal in probing into the past which went behind the sculptures and paintings. He comprehends this fact of history in all its complexity social, moral and human giving a comprehensive vision of life. In his novel, India: A Wounded Civilization Indian sculpture and architecture comes in for treatment in a major way. In a surprising revelation he proclaims in the later book that Indian sculpture was worth all the sculpture of the rest of the world. One gets a glimpse of this from the text: "Yet Jaisalmer is famous for its old architecture, its palaces, and the almost Venetian grandeur of some of its streets. And in the bazaar area there are traditional courtyard houses, ...always in cool shadow" (127). Naipaul recaptures the idyllic world of his childhood, but it is only an old childhood Hindu world he can peacefully and joyously relate to. This world is conjured up again when Naipaul goes on a yatra to the shrine of Shiva at Amarnath. Naipaul briefly experiences the security and joy of belonging to a country and possessing a home, when his Brahmin sensibility relates his experiences in India to what he had experienced as a boy in Trinidad. In such moments, Naipaul is willing to remain open to the "presence" of the country. But when the experience and familiar awareness of childhood are not encountered, Naipaul tends to attack India with Western bias, on the basis of Western categories.

One cannot really understand why Naipaul has so much contempt for Jaya Prakash Narayan who is portrayed to be protesting, and a sterile in his political life. Naipaul is very harsh when he points out that this Gandhians had historical fantasy with religious exaltation and they wholly depended upon the success of Gandhi. To substantiate this he quotes a scene from his acquaintance with a young woman:

And this was what was attempted by another young woman, a friend of the couple who lived abroad. The women of Bombay, she said, and she meant the women of the lower castes, wore a certain kind of sari and preferred certain colours; the men wore a special kind of turban. (117)

India is then portrayed as corrupted by power and mercenary greed. Naipaul portrays Indians and their opinion about Indian politics and to substantiate this point he brings to picture a lady from Delhi. The following line 
picturises what she felt to be an Indian 'We are like a zoo,' the melancholy middle-class lady said in Delhi. "Perhaps we should charge" (135).

To strengthen his stand, Naipaul states that the lady's intention was to rebuke, possibly an insult, for it was easy to let the anger pass without strong words. According to Naipaul, India was like a zoo because India was poor and cruel and had lost its way. These were things about India. The lady, like other middle-class people, felt secure in her caste world. She might have been able to detach herself from the mess of India, but when she felt she was going down with it, all she could do was an outburst on what the politician did at the Centre. Naipaul then brings out the Emergency Period declared by the then Prime Minister, Mrs. Indira Gandhi. The disgust that people held over the Indian political set-up doubled. As in the case of political parties, they were either banned or their leaders imprisoned with many others; and people outside who were concerned about the rule of law in India found themselves disconcerned by the causes they have found themselves sponsoring. This disgust takes a different track when Naipaul goes ahead in his description about Indian jails.

One opposition pamphlet now being circulated is about the torture of political prisoners in Indian jails. The torture, it must be said, is not of the systematized South American variety; it is more an affair of random brutality. But the power of the police in India is now unlimited and the pamphlet doesn't exaggerate. It leaves out only the fact that there has always been torture of this sort in Indian jails. Torture, like poverty, is something about Indians have just discovered. (115)

Indian landscape has come in for lot of appreciation from V.S.Naipaul. The Dal Lake, Shimla, Jammu and Kashmir, Vijayanagar Empire, Bombay, Calcutta, and Goa harbour are meticulously described. Naipaul is alternatively, an Indian in India, and a Westerner in India. Naipaul's joy, exhilaration and exultation come from his former self; his anger and negativity from the later self. His flight from India punctuated by his brief returns to the pattern of venture and withdrawal expresses perfectly the dilemma of the expatriate self.

V.S.Naipaul's opinion on India is a prejudiced one. V.S. Naipaul came to India to recapitulate and get back his childhood memories of India. He had come with expectation in heart, but what India offered, shattered his nostalgia. One can easily perceive an outsider in Naipaul, though he belongs to India. India: A Wounded Civilization classified by its publishers as Travel/Current Events, assemble a postcolonial traveller's impressions of India, arising from his visits to this country and travels within it, but related more to people and issues than places. Destinations were important, not for the natural and man-made attractions they offered to the traveler, but the socio-politico-economic movements he saw here. Naipaul was not bound by his itinerary. His quest for understanding what he saw in India, and the interest in interpreting it to the west grew with every visit. It would be too blunt to conclude that his writing is a personal travelogue, but it would be right on our part to say that his writing is a portrayal of what India was and what India is heading towards. One can really add a feather to his appraisal of the Indian past.

In short, it can be said that by interweaving Brahmanical past with his Trinidadian present one can project him to be a perfect vehicle to report the microcosm and the macrocosm of the expatriate sensibility in him. Naipaul's ideas seem to be an elemental symbiosis of man and nature that he belongs to. Besides, Naipaul's identity remains the most controversial, yet a successful documentary novel. Expatriate vision is obvious everywhere in his work.

\section{References:}

[1] Dangwal, Surekha. “An Area of Darkness: The Document of Diasporic Experiences of V.S.Naipaul”. The Commonwealth Review, Vol. 11, No.2, 1999-2000.

[2] Jain, Jasbir and Veena Singh.Contesting Post-Colonialisms. Rawat Publications, Jaipur, 2000.

[3] Landeg, White. V.S.Naipaul: A Critical Introduction. Macmillan, London, 1975.

[4] Naipaul,V.S. India: A Wounded Civilization. Penguin Publishers,Calcutta, 1977.

[5] Patel, Vasant. "V.S.Naipaul: An Expatriate", Commonwealth Writing: A Study in Expatriate Experience. Ed. Dhawan R.K.and L.S.R.Krishna Sastry, Prestige Books, New Delhi, 1994.

[6] Rai, Sudha. A Study in Expatriate Sensibility: V.S.Naipaul. FirstPublished, New Delhi, 1982.

[7] Singh, ManjitInder. "Writers of the Indian Diaspora: V.S.Naipaul”. Rawat Publications, New Delhi, 1998.

\section{Website}

[8] http://www.indiaclub.com 